The Perception of Auditor Career From University Student Perspective by Muhammad Reza Ramdani, Andi Muara Arum Barkah, Ismi Ayu Lestari

\title{
The Perception of Auditor Career From University Students Perspective
}

\author{
Muhammad Reza Ramdani *) \\ Andi Muara Arumbarkah **) \\ Ismi Ayu Lestari ***)
}

\begin{abstract}
This study explores the perceptions of accounting students about their selection in a career as an auditor through several indicators. This study aims to see what is the indicator that matter to students in in choosing career as auditors. The approach used was quantitative descriptive. The total sample of 100 students from Muslim University of Indonesia and Muhammadiyah University of Makassar. The method of data collection was through questionnaires distributed to students and by purposive sampling method and processed by regression analysis. The results of the study showed that financial appreciation, professional recognition, and market considerations have a positive and significant effect while professional training, work environment and personality have a positive and not significant effect on auditor career selection and social value variables that have a negative and insignificant effect on career choice as an auditor. Financial award is a dominant variable in the career choice of students as auditors.
\end{abstract}

Keywords: Perception; Auditor; Career; Accountant; Student

\section{INTRODUCTION}

\subsection{Research Background}

Nowadays the importance of an auditor career is growing massively. Especially in Makassar, there are only seven Public Accounting Firms and 40 auditors. Although from year to year public interest in the accounting profession is quite high from year to year, which provides accounting education services at various levels, including undergraduate education (S1). The various types of careers that can be pursued by accounting scholars show that every accounting graduate is free to choose what career he will pursue (Rahayu, Sudaryono, \& Setiawan, 2003). Bachelor of accounting has at least three alternative steps that can be taken. First, after completing economics education majoring in accounting, one can immediately work. Second, continuing academic education at the Undergraduate level. Third, continuing professional education to become a public accountant. In other words, after completing an education at the undergraduate degree majoring in accounting, accounting graduates can choose to work as public accountants or non-public accountants. Career selection is an individual process such as an effort to prepare to enter the stages associate with work (Setyawardani, 2009). Undergraduate accounting decisions to choose an auditor's career need careful consideration including incentives, professional training, professional recognition, social values, work environment, and job market. They must go through a rigorous selection process to get the title of the professional auditor. This is needed to be able to distinguish the level of quality and ability of the certificate holder with those who do not have a certificate. The existence of difficult process is not a few of accounting scholars withdraw their intention to become auditors except those who have broad competence and believe that they can go through the selection process (Ramdani \& Kamidin, 2018).

The career choice of accounting students is influenced by several factors, such as financial or salary awards, professional training, professional recognition, social values, work environment, job security, and ease of access to job vacancies (Putra \& Silfi, 2016). The factors that influence the 
career choice of students and type of career they will pursue are interesting things to study because the knowledge of career choices students is interested, it can be seen the reasons for choosing a career (Rahayu, Sudaryono, \& Setiawan, 2003). Then the researcher wants to explore student perceptions of financial awards, professional training, professional recognition, social values, work environment, and work environment towards the selection of their careers for the profession of auditors, so they can find out benchmarks of students in choosing a career as auditors.

\subsection{Research Problem}

Based on research background above, this study needs to evaluate the perception of auditor career that consists of perception on a financial award, professional training, professional recognition, social value, work environment, market consideration, and personality from the university students perspective.

\subsection{Research Purpose}

This study needs to evaluate the perception of auditor career that consists of perception on the financial award, professional training, professional recognition, social value, work environment, market consideration, and personality from a university student perspective.

\section{THEORETICAL FRAMEWORK AND HYPOTHESES DEVELOPMENT}

Professional training does not significantly influence career choice like a public accountant because the career into chosen is not far from the knowledge gained by college, so it does not focus on job training. In addition to professional training, professional recognition is also considered in career selection (Suyono, 2014). Someone works not only to meet financial needs but to get recognition of achievement and develop themselves. This is not in line with 's research where professional recognition has no significant effect on career choice. The three factors above are financial awards, professional training, and professional recognition are mutually supportive factors. Rational financial awards are a fundamental requirement of job satisfaction. However, this is not easy to obtain. Being an auditor requires a lot of work experience to avoid mistakes of giving conclusions and audit reports. Social values are shown as factors that reveal a person's ability to his community or one's values from the point of view of those around him (Suyono, 2014). The work environment has a significant effect on the profession selection toward auditors (Putra \& Silfi, 2016). Unlike stated that the work environment does not affect career choice. But this is about not in line with the result of Merdekawati \& Sulistyawati (2012) which concluded that market considerations did not affect career choice.

This seems that the desire of students in principle to work is inseparable from the field of accounting. In addition to financial factors, professional recognition, professional training, social values, work environment, and market considerations, there is one more important factor in this study that is personality factors. Personality factors talk about the personality of each person differently. Rahayu, Sudaryono, \& Setiawan, (2003) stated that personality is one of the potential determinants of individual behavior when dealing with certain situations/conditions especially in choosing a career. Likewise, Putra \& Silfi (2016) study concluded that personality factors have a significant effect on career selection. However, different from the results of Merdekawati \& Sulistyawati (2012) and Yanti \& Ratnawati (2014) stated that personality factors did not affect student career selection. 


\subsection{Financial Reward}

Financial incentives linked to academic performance have been proposed as a potentially cost-effective way to support improvement. Treated students perform better than those in control of the same non-incented test (List et al., 2018). The study which included financial rewards were initial salary, pension fund, and the potential increase in financial reward/salary. Wheeler (1993) and Astuti (2014) found that business people, psychology, and education in addition to accountant public (Auditor) assume that this profession offers higher income than jobs in marketing, general management, finance, and banking. Financial reward and career auditor relationships perceive that the profession of auditors has relatively high salaries compared to other professions.

$\mathrm{H}_{1}$ : Financial reward has a positive and significant effect on auditor career choice.

\subsection{Professional Training}

Professional training is considered by students who choose the profession of government auditors (Astuti, 2014). It means that in choosing a profession student not only seeking financial rewards but also to pursue achievements and develop themselves.

$\mathrm{H}_{2}$ : Professional training has a positive and significant effect on auditor career choice.

\subsection{Professional Recognition}

Professional recognition is related to the recognition of an achievement (work results) stated that professional recognition is considered by students who choose the profession of public accountant. It means that choosing a profession is not only aimed at seeking financial expectations but also there is a desire for recognition of achievement and self-development. Professional recognition that will be tested in this study includes opportunities to develop, recognition achievers, special skills in work, easy to get promoted, and opportunities to compete (Merdekawati \& Sulistiyawati, 2012). Easy to rise in rank.

$\mathrm{H}_{3}$ : Professional recognition factor has a positive and significant effect on the auditor career choice.

\subsection{Social Value}

Social values are intended as a factor that shows a person's ability from the point through view other people towards his environment (Wijayanti, 2001). Shows that social values are shown as factors that reveal a personal ability to society or in other words the value for someone toward the point of view through other people in their environment. The auditor profession enhances social quality in people's views of them.

$\mathrm{H}_{4}$ : Factors of social values have a positive and significant effect on auditor career choice.

\subsection{Work Environment}

The work environment is everything in around the workers and which can affect themselves in carrying out the tasks that are charged (Nitisemito, 2001). The work environment in government auditors is a work environment that more required to face challenges because with the variety of services provided by clients be able to lead various types of work pressure to achieve perfect results (Aprilyan, 2011). The work environment that struggles in the financial sector makes a person become challenged and can improve abilities. World auditors themselves have an environment that is familiar with financial checks so they can improve performance.

$\mathrm{H}_{5}$ : Work environment factors have a positive and significant effect on auditor career choice. 


\subsection{Market Consideration}

The labor market is all the needs and supplies out of labor or all requests and offers in the community with all the mechanisms that allow productive transactions among people to sell their labor with the employers who need the labor (Suroto, 1990). While Simanjuntak (2001) stated that the job market is all activities of the actors that bring together job seekers and job openings individuals who are engaged in the profession of auditors for power market, especially in the city of Makassar are still relatively small compared to the number of other professions. It becomes an application of labor for the profession of auditors. This actor consists of who needs an entrepreneur, job seekers, intermediaries or third parties that make it easy for employers and job seekers to interact with each other.

$\mathrm{H}_{6}$ : Market consideration factors have a positive and significant effect on the auditor career choice.

\subsection{Personality}

Personality is one of the potential determinants of individual behavior when dealing with certain situations/conditions. Personality shows how to control or reflect a person's personality at work. Personality will form individuals; an auditor indirectly shapes his personality into a person who is skilled, disciplined, thorough and flexible and puts independence first. This is the reason for the relationship between the formation of personal individuals and the profession of auditors.

$\mathrm{H}_{7}$ : Personality factors have a positive and significant effect on auditor career choice.

\section{RESEARCH METHOD}

\subsection{Research Design}

This study used a descriptive quantitative approach and was conducted at two universities namely the Faculty of Economy, Muslim University of Indonesia and Muhammadiyah University of Makassar. This study held in March - June 2018. The data sources used in this study was obtained directly from respondents. Data collection at this study was a questionnaire that upon spreading a list of the states have been compiled, and then respondents were asked to answer according to their opinions. All instruments used an ordinal Likert scale with a score of 1 (Strongly Disagree) - 5 (Strongly Agree).

Table 2 Variable and Indicator

\begin{tabular}{|c|l|l|c|}
\hline Variable & \multicolumn{1}{|c|}{ Definition } & \multicolumn{1}{c|}{ Indicator } & Source \\
\hline Awancial & $\begin{array}{l}\text { Special compensation was } \\
\text { given to increase individual } \\
\text { performance, apart from what } \\
\text { should be obtained from his } \\
\text { work. }\end{array}$ & $\begin{array}{l}\text { Careers that provide high initial } \\
\text { salaries, relatively fast salary } \\
\text { increase, providing pension funds, } \\
\text { careers that provide work bonus, } \\
\text { There is no fixed income guarantee, } \\
\text { careers that provide home facilities }\end{array}$ & $\begin{array}{c}\text { List, Livingston, } \\
\text { Neckermann } \\
\text { (2018) }\end{array}$ \\
\hline $\begin{array}{c}\text { Professional } \\
\text { Training }\end{array}$ & $\begin{array}{l}\text { Professional training covers } \\
\text { matters related to increasing } \\
\text { expertise, skills, and } \\
\text { knowledge. Professional } \\
\text { recognition includes } \\
\text { recognition of achievement }\end{array}$ & $\begin{array}{l}\text { Training before starting work } \\
\text { training outside the institution, } \\
\text { regular job training within the } \\
\text { institution, work experience that } \\
\text { does not vary }\end{array}$ & Crowley (2017). \\
\hline
\end{tabular}


JEMA: Jurnal Ilmiah Bidang Akuntansi dan Manajemen, Vol. 16 No. 1 (2019)

http://riset.unisma.ac.id/index.php/jema (e-ISSN : 2597-4071)

\begin{tabular}{|c|c|c|c|}
\hline Variable & Definition & Indicator & Source \\
\hline $\begin{array}{l}\text { Professional } \\
\text { Recognition }\end{array}$ & $\begin{array}{l}\text { With the recognition of work, } \\
\text { performance will be able to } \\
\text { improve the quality of work } \\
\text { produced and can increase } \\
\text { motivation in achieving a } \\
\text { better career. This factor can } \\
\text { improve and foster the } \\
\text { development of the company } \\
\text { or individual itself. }\end{array}$ & $\begin{array}{l}\text { More opportunities to develop, } \\
\text { there is recognition of achievement } \\
\text { for the services provided, requires } \\
\text { expertise into work, there is no } \\
\text { chance to compete, easy to rise in } \\
\text { rank }\end{array}$ & $\begin{array}{l}\text { Sulistyawati, } \\
\text { Ernawati, \& } \\
\text { Sylviana (2013) }\end{array}$ \\
\hline Social Value & $\begin{array}{l}\text { Expressing sociology views } \\
\text { values as notions (something } \\
\text { in people's heads) about the } \\
\text { good or not of actions. In } \\
\text { other words, the value is the } \\
\text { result of moral judgment or } \\
\text { judgment. }\end{array}$ & $\begin{array}{l}\text { Opportunity to do social activities, } \\
\text { it's easier to interact with other } \\
\text { people, the opportunity to run a } \\
\text { hobby, want to be appreciated, } \\
\text { work with experts in other fields }\end{array}$ & Sari (2014) \\
\hline $\begin{array}{c}\text { Work } \\
\text { Environment }\end{array}$ & $\begin{array}{l}\text { Work environment has a big } \\
\text { influence on work } \\
\text { effectiveness and orientation. } \\
\text { Therefore, the work } \\
\text { environment will provide a } \\
\text { new atmosphere for him } \\
\text { which will have an influence } \\
\text { on the successful } \\
\text { implementation of his duties } \\
\text { to the work. }\end{array}$ & $\begin{array}{l}\text { Regular work, many challenges, } \\
\text { flexible working hours } \\
\text { (changeable), Frequent overtime, } \\
\text { there is no work pressure to achieve } \\
\text { perfect results }\end{array}$ & $\begin{array}{l}\text { Tumiwa, Tewal, \& } \\
\text { Palandeng (2017) }\end{array}$ \\
\hline $\begin{array}{c}\text { Market } \\
\text { Consideration }\end{array}$ & $\begin{array}{l}\text { One of the most important } \\
\text { factors that determine } \\
\text { individuals' quality of life and } \\
\text { wellbeing is their position in } \\
\text { the labor market and the type } \\
\text { of jobs that they hold. When } \\
\text { workers are rationed out of } \\
\text { the formal segment of the } \\
\text { labor market against their } \\
\text { will, i.e., the labor market is } \\
\text { segmented, their quality of } \\
\text { life is limited, and their } \\
\text { wellbeing is reduced }\end{array}$ & $\begin{array}{l}\text { Ease of accessing job vacancies, } \\
\text { career auditors are much needed }\end{array}$ & $\begin{array}{c}\text { Lehmann \& } \\
\text { Pignatti (2018). }\end{array}$ \\
\hline Personality & $\begin{array}{l}\text { Personality measures that can } \\
\text { help explain economic values } \\
\text { and choices systematically }\end{array}$ & $\begin{array}{l}\text { Suitability of work with one's } \\
\text { personality, not easily affected and } \\
\text { impartial, to be responsible, high } \\
\text { discipline }\end{array}$ & $\begin{array}{c}\text { Boyce, } \\
\text { Czajkowski, \& } \\
\text { Hanley (2018). }\end{array}$ \\
\hline
\end{tabular}


JEMA: Jurnal Ilmiah Bidang Akuntansi dan Manajemen, Vol. 16 No. 1 (2019)

http://riset.unisma.ac.id/index.php/jema (e-ISSN : 2597-4071)

\begin{tabular}{|l|l|l|c|}
\hline \multicolumn{1}{|c|}{ Variable } & \multicolumn{1}{|c|}{ Definition } & \multicolumn{1}{c|}{ Indicator } & \multicolumn{1}{c|}{ Source } \\
\hline Career Auditor & $\begin{array}{l}\text { An auditor is someone who } \\
\text { expresses an opinion on } \\
\text { fairness in all material } \\
\text { respects, the financial position } \\
\text { of business results and cash } \\
\text { flows that are by accounting } \\
\text { principles generally accepted } \\
\text { in Indonesia }\end{array}$ & $\begin{array}{l}\text { A trusted business consultant } \\
\text { auditor, auditors expand accounting } \\
\text { insight, professional auditors in } \\
\text { accounting, the auditor receives the } \\
\text { appropriate benefits, auditors are } \\
\text { often overtime and work intensive, } \\
\text { personal satisfaction can be } \\
\text { achieved, a career whose work } \\
\text { security is guaranteed, auditors } \\
\text { obtain high expectations in the } \\
\text { community. }\end{array}$ & $\begin{array}{l}\text { Arens, } \\
\text { Beasley (2002). }\end{array}$ \\
\hline
\end{tabular}

\subsection{Population and Sample}

The sample of this study are accounting students who are considered to have an alternative plans or thoughts about what will be done after graduating from the undergraduate program. The sample collection method used in this study was non-probability sampling (accidental sampling)

Table 1 Research Population

\begin{tabular}{|l|l|c|}
\hline No. & University & Number of Students \\
\hline 1. & Muslim University of Indonesia & 530 \\
\hline 2. & Muhammadiyah University of Makassar & 539 \\
\hline \multicolumn{2}{|c|}{ Total Population } & 1.069 \\
\hline
\end{tabular}

\subsection{Research Framework}

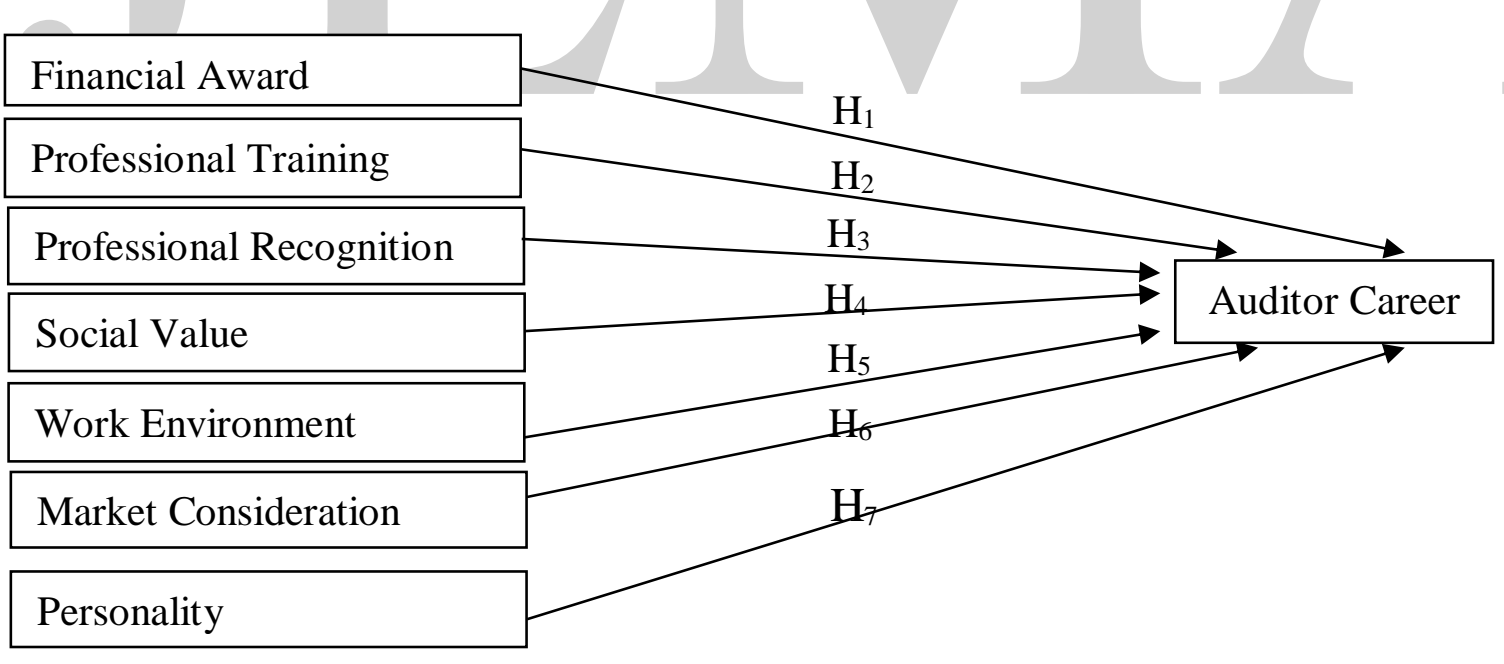

Picture 1 Research Framework

This study employs seven main variables; Financial Award, Professional Training, Professional Recognition, Social Value, Work Environment, Market Consideration, Personality and Career Auditor as seen in the table below. 
JEMA: Jurnal Ilmiah Bidang Akuntansi dan Manajemen, Vol. 16 No. 1 (2019)

http://riset.unisma.ac.id/index.php/jema (e-ISSN : 2597-4071)

\section{RESEARCH RESULT AND ANALYSIS}

\subsection{Descriptive Analysis}

The majority of respondent in this research are female $(63 \%)$ with most of them already though auditors as career choice. The reason of student in pursuing career as auditor is because they know that auditor offers many benefit especially financial reward.

\subsection{Validity and Reliability}

Table 3 Validity Result

\begin{tabular}{|c|c|c|c|c|c|c|c|c|c|}
\hline Item & $\mathrm{R}_{\text {value }}$ & $\mathrm{R}_{\text {table }}$ & Rule of Thumb & Decision & Item & $\mathrm{R}_{\text {value }}$ & $\mathrm{R}_{\text {table }}$ & Rule of Thumb & Decision \\
\hline 1 & ,444 & ,2061 & $\mathrm{R}_{\text {value }}>\mathrm{R}_{\text {table }}$ & Valid & 22 &, 439 & ,2061 & $R_{\text {value }}>R_{\text {table }}$ & Valid \\
\hline 2 &, 523 & ,2061 & $\mathrm{R}_{\text {value }}>\mathrm{R}_{\text {table }}$ & Valid & 23 &, 527 & ,2061 & $\mathrm{R}_{\text {value }}>\mathrm{R}_{\text {table }}$ & Valid \\
\hline 3 &, 522 & ,2061 & $\mathrm{R}_{\text {value }}>\mathrm{R}_{\text {table }}$ & Valid & 24 &, 498 & ,2061 & $\mathrm{R}_{\text {value }}>\mathrm{R}_{\text {table }}$ & Valid \\
\hline 4 & ,401 & ,2061 & $\mathrm{R}_{\text {value }}>\mathrm{R}_{\text {table }}$ & Valid & 25 & ,338 & ,2061 & $\mathrm{R}_{\text {value }}>\mathrm{R}_{\text {table }}$ & Valid \\
\hline 5 & ,471 & ,2061 & $\mathrm{R}_{\text {value }}>\mathrm{R}_{\text {table }}$ & Valid & 26 & ,468 & ,2061 & $\mathrm{R}_{\text {value }}>\mathrm{R}_{\text {table }}$ & Valid \\
\hline 6 & ,481 & ,2061 & $\mathrm{R}_{\text {value }}>\mathrm{R}_{\text {table }}$ & Valid & 27 &, 456 & ,2061 & $\mathrm{R}_{\text {value }}>\mathrm{R}_{\text {table }}$ & Valid \\
\hline 7 &, 425 & ,2061 & $\mathrm{R}_{\text {value }}>\mathrm{R}_{\text {table }}$ & Valid & 28 & ,449 & ,2061 & $\mathrm{R}_{\text {value }}>\mathrm{R}_{\text {table }}$ & Valid \\
\hline 8 &, 615 & ,2061 & $\mathrm{R}_{\text {value }}>\mathrm{R}_{\text {table }}$ & Valid & 29 & ,354 & ,2061 & $\mathrm{R}_{\text {value }}>\mathrm{R}_{\text {table }}$ & Valid \\
\hline 9 &, 621 & ,2061 & $\mathrm{R}_{\text {value }}>\mathrm{R}_{\text {table }}$ & Valid & 30 & ,305 & ,2061 & $\mathrm{R}_{\text {value }}>\mathrm{R}_{\text {table }}$ & Valid \\
\hline 10 & ,462 & ,2061 & $\mathrm{R}_{\text {value }}>\mathrm{R}_{\text {table }}$ & Valid & 31 &, 587 & ,2061 & $\mathrm{R}_{\text {value }}>\mathrm{R}_{\text {table }}$ & Valid \\
\hline 11 &, 555 & ,2061 & $\mathrm{R}_{\text {value }}>\mathrm{R}_{\text {table }}$ & Valid & 32 &, 363 & ,2061 & $R_{\text {value }}>R_{\text {table }}$ & Valid \\
\hline 12 &, 496 & ,2061 & $\mathrm{R}_{\text {value }}>\mathrm{R}_{\text {table }}$ & Valid & 33 &, 414 & ,2061 & $\mathrm{R}_{\text {value }}>\mathrm{R}_{\text {table }}$ & Valid \\
\hline 13 & ,431 & ,2061 & $\mathrm{R}_{\text {value }}>\mathrm{R}_{\text {table }}$ & Valid & 34 &, 414 & ,2061 & $\mathrm{R}_{\text {value }}>\mathrm{R}_{\text {table }}$ & Valid \\
\hline 14 & 265 & ,2061 & $\mathrm{R}_{\text {value }}>\mathrm{R}_{\text {table }}$ & Valid & 35 &, 406 & ,2061 & $\mathrm{R}_{\text {value }}>\mathrm{R}_{\text {table }}$ & Valid \\
\hline 15 &, 475 & ,2061 & $\mathrm{R}_{\text {value }}>\mathrm{R}_{\text {table }}$ & Valid & 36 &, 488 & ,2061 & $\mathrm{R}_{\text {value }}>\mathrm{R}_{\text {table }}$ & Valid \\
\hline 16 &, 381 & ,2061 & $\mathrm{R}_{\text {value }}>\mathrm{R}_{\text {table }}$ & Valid & 37 &, 574 & ,2061 & $\mathrm{R}_{\text {value }}>\mathrm{R}_{\text {table }}$ & Valid \\
\hline 17 & 473 & ,2061 & $R_{\text {value }}>R_{\text {table }}$ & Valid & 38 &, 362 &, 2061 & $\mathrm{R}_{\text {value }}>\mathrm{R}_{\text {table }}$ & Valid \\
\hline 18 & ,484 & ,2061 & $\mathrm{R}_{\text {value }}>\mathrm{R}_{\text {table }}$ & Valid & 39 & ,408 & ,2061 & $\mathrm{R}_{\text {value }}>\mathrm{R}_{\text {table }}$ & Valid \\
\hline 19 & ,269 & ,2061 & $\mathrm{R}_{\text {value }}>\mathrm{R}_{\text {table }}$ & Valid & 40 & ,226 & ,2061 & $\mathrm{R}_{\text {value }}>\mathrm{R}_{\text {table }}$ & Valid \\
\hline 20 & , 410 & ,2061 & $\mathrm{R}_{\text {value }}>\mathrm{R}_{\text {table }}$ & Valid & 41 & ,266 & ,2061 & $R_{\text {value }}>R_{\text {table }}$ & Valid \\
\hline 21 &, 558 & ,2061 & $\mathrm{R}_{\text {value }}>\mathrm{R}_{\text {table }}$ & Valid & & & & & \\
\hline
\end{tabular}

Source: Primary Data Processed, 2018

The table above shows that all statement items have positive correlation coefficients and greater than r-table 0.2061. It means that the data obtained is valid and further testing of data can be done. 
JEMA: Jurnal Ilmiah Bidang Akuntansi dan Manajemen, Vol. 16 No. 1 (2019)

http://riset.unisma.ac.id/index.php/jema (e-ISSN : 2597-4071)

Table 4 Reliability Result

\begin{tabular}{|c|c|c|c|c|c|c|c|}
\hline Item & $\begin{array}{c}\text { Cronbach's } \\
\text { Alpha of } \\
\text { Item Deleted }\end{array}$ & $\begin{array}{c}\text { Rule of } \\
\text { Thumb }\end{array}$ & Decision & Item & $\begin{array}{c}\text { Cronbach's } \\
\text { Alpha of } \\
\text { Item Deleted }\end{array}$ & $\begin{array}{c}\text { Rule of } \\
\text { Thumb }\end{array}$ & Decision \\
\hline 1 &, 915 & $>0.60$ & Reliable & 22 &, 915 & $>0.60$ & Reliable \\
\hline 2 &, 914 & $>0.60$ & Reliable & 23 &, 914 & $>0.60$ & Reliable \\
\hline 3 &, 914 & $>0.60$ & Reliable & 24 &, 915 & $>0.60$ & Reliable \\
\hline 4 &, 916 & $>0.60$ & Reliable & 25 &, 916 & $>0.60$ & Reliable \\
\hline 5 &, 915 & $>0.60$ & Reliable & 26 &, 915 & $>0.60$ & Reliable \\
\hline 6 &, 915 & $>0.60$ & Reliable & 27 &, 915 & $>0.60$ & Reliable \\
\hline 7 &, 915 & $>0.60$ & Reliable & 28 &, 915 & $>0.60$ & Reliable \\
\hline 8 &, 913 & $>0.60$ & Reliable & 29 &, 916 & $>0.60$ & Reliable \\
\hline 9 &, 913 & $>0.60$ & Reliable & 30 &, 917 & $>0.60$ & Reliable \\
\hline 10 &, 915 & $>0.60$ & Reliable & 31 &, 914 & $>0.60$ & Reliable \\
\hline 11 &, 914 & $>0.60$ & Reliable & 32 &, 916 & $>0.60$ & Reliable \\
\hline 12 &, 915 & $>0.60$ & Reliable & 33 &, 916 & $>0.60$ & Reliable \\
\hline 13 &, 915 & $>0.60$ & Reliable & 34 &, 916 & $>0.60$ & Reliable \\
\hline 14 &, 917 & $>0.60$ & Reliable & 35 &, 916 & $>0.60$ & Reliable \\
\hline 15 &, 915 & $>0.60$ & Reliable & 36 &, 915 & $>0.60$ & Reliable \\
\hline 16 &, 916 & $>0.60$ & Reliable & 37 &, 914 & $>0.60$ & Reliable \\
\hline 17 &, 915 & $>0.60$ & Reliable & 38 &, 916 & $>0.60$ & Reliable \\
\hline 18 &, 915 & $>0.60$ & Reliable & 39 &, 916 & $>0.60$ & Reliable \\
\hline 19 &, 917 & $>0.60$ & Reliable & 40 &, 918 & $>0.60$ & Reliable \\
\hline 20 &, 916 & $>0.60$ & Reliable & 41 &, 917 & $>0.60$ & Reliable \\
\hline 21 &, 914 & $>0.60$ & Reliable & & & & \\
\hline
\end{tabular}

Source: Primary Data Processed, 2018

Based on the table above the results of the data reliability test above, shows that each item has an alpha coefficient> of 0.60 so that all items are declared reliable and can be used for further testing.

\subsection{Research Analysis}

Table 5 Collinearity Result

\begin{tabular}{|l|r|r|}
\hline \multirow{2}{*}{\multicolumn{1}{|c|}{ Variable }} & \multicolumn{2}{c|}{ Collinearity Statistics } \\
\cline { 2 - 3 } & Tolerance & \multicolumn{1}{c|}{ VIF } \\
\hline Financial Award &, 698 & 1,433 \\
\hline Professional Training &, 625 & 1,600 \\
\hline Professional Recognition &, 476 & 2,103 \\
\hline Social Value &, 577 & 1,734 \\
\hline Work Environment &, 553 & 1,807 \\
\hline Market Consideration &, 672 & 1,489 \\
\hline Personality &, 735 & 1,360 \\
\hline
\end{tabular}

Source: Primary Data Processed, 2018 
The independent variable has a Variance Inflation Factor (VIF) value of about 1 to 10 , as well as the results of the tolerance value of more than 0.10 ; it can be concluded that there is no multicollinearity problem between independent variables.

\section{Normal P-P Plot of Regression Standardized Residual}

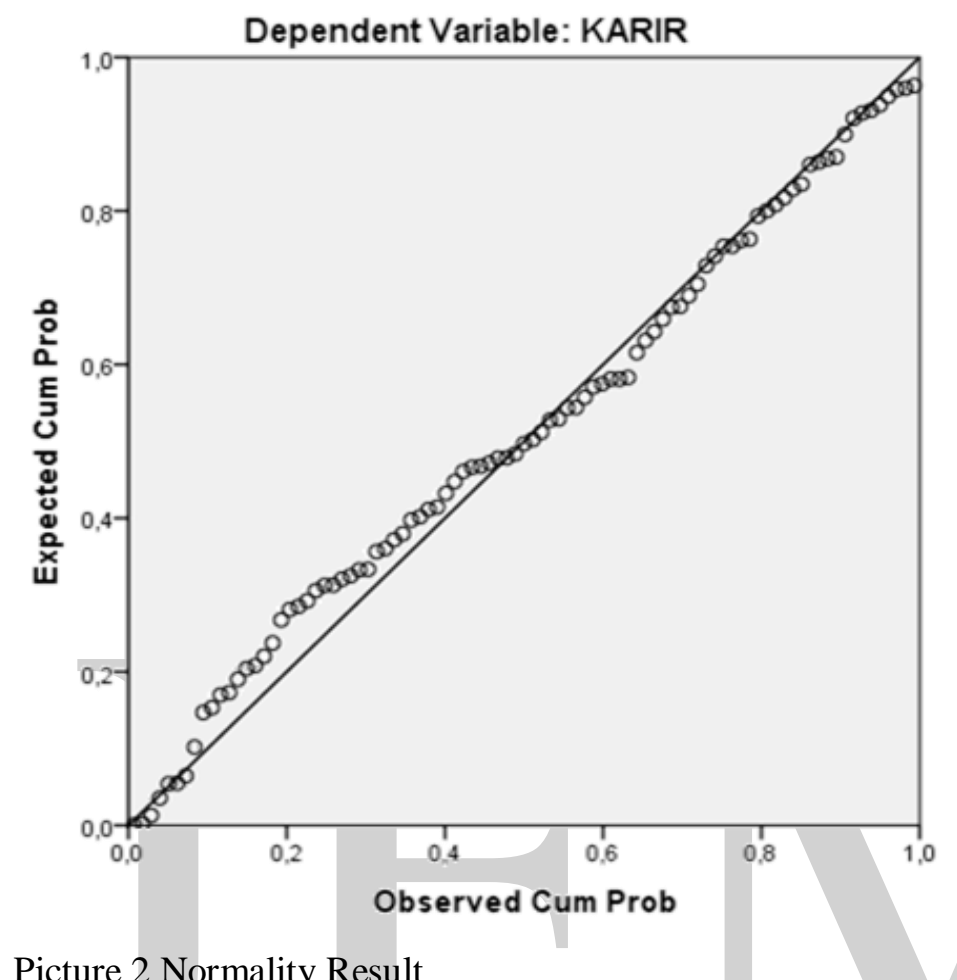

Picture 2 Normality Result
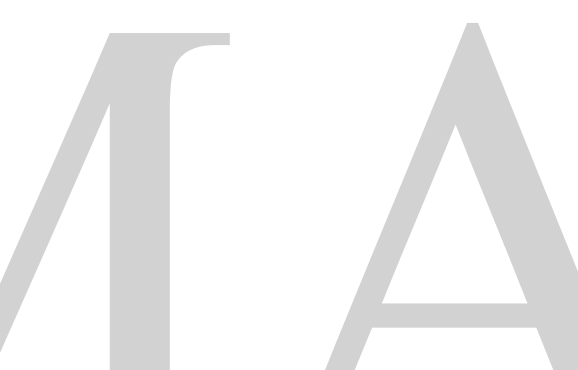

It can be seen that the data points spread around the diagonal line and follow the direction of the diagonal line, so the data model meets the assumption of normality.

\subsection{Research Discussion}

Table 6 The Contribution of Variable

\begin{tabular}{|c|r|r|r|r|}
\hline $\mathrm{R}$ & $\mathrm{R}$ Square & Adjusted R Square & Std. An error of the Estimate & Durbin-Watson \\
\hline, $738^{\mathrm{a}}$ &, 545 &, 507 &, 41775 & 2,056 \\
\hline
\end{tabular}

Source: Primary Data Processed, 2018

The adjusted $\mathrm{R}^{2}$ value is 0.507 , means that the contribution of the financial reward, professional training, professional recognition, social values, work environment, market consideration, and personality toward the auditor career choice is $50.7 \%$, while the rest of $49.3 \%$ influenced by other variables which excluded from this model.

Based on regression result (Table 7), it can be concluded that accounting students consider higher initial salaries, relatively fast salary increases the availability of pension funds, bonus, and facilities to be considered in the auditor's career selection. This is also seen in the results of the respondent's responses and the results of descriptive statistics which as a whole are on the scale/category agreed. Primarily in the fourth revelation item, accounting students agree with the career statement, the auditor provides a work bonus. This fourth statement item has the highest total frequency of other statement items. The more bonus is given, the higher the income earned. The 
existence of a high financial / salary award is expected by accounting students to be able to fulfill their future life needs. The results of this study are in line with the research conducted List, Livingston, \& Neckermann (2018). Special compensation given to increase individual performance, apart from what should be obtained from his work.

Table 7 Regression Analysis

\begin{tabular}{|l|c|c|c|c|c|}
\hline \multirow{2}{*}{ Variable } & \multicolumn{2}{|c|}{$\begin{array}{c}\text { Unstandardized } \\
\text { Coefficients }\end{array}$} & $\begin{array}{c}\text { Standardized } \\
\text { Coefficients }\end{array}$ & \multirow{2}{*}{$\mathrm{t}$} & \multirow{2}{*}{ Sig. } \\
\cline { 2 - 4 } & $\mathrm{B}$ & Std. Error & Beta & & \\
\hline (Constant) &, 330 &, 349 & - &, 944 &, 348 \\
\hline Financial Reward &, 301 &, 079 &, 336 & 3,788 &, 000 \\
\hline Professional Training &, 070 &, 092 &, 071 &, 763 &, 448 \\
\hline Professional Recognition &, 247 &, 106 &, 249 & 2,323 &, 023 \\
\hline Social Value &,- 012 &, 096 &,- 012 &,- 124 &, 902 \\
\hline Work Environment &, 128 &, 104 &, 123 & 1,231 &, 222 \\
\hline Market Consideration &, 163 &, 074 &, 200 & 2,217 &, 029 \\
\hline Personality &, 015 &, 083 &, 015 &, 176 &, 861 \\
\hline
\end{tabular}

Source: Primary Data Processed, 2018

Based on the results of the data, there are still some respondents who disagree when professional training is taken into consideration in the career choice of auditors. They see that professional training namely training carried out before work, training in institutions and training outside the institution does not become a guarantee in career selection, because the career to be chosen is not much different from the knowledge that has been obtained from the lecture bench. The knowledge or ability has been obtained at the time of the lecture is the basis for them to work. So, they assume that choosing a career is not focused on job training. The results of this study are in line with the results of (Astuti, 2014), namely that professional training factors have no significant effect on career choice as an auditor.

Accounting students agree that in choosing the career of an auditor not only consider the factors of financial rewards but also require recognition of an achievement. This recognition can be categorized as an intangible financial award given to workers as a reward or gift, so the individual or worker continues to improve his performance and get the right to work has been done in achieving an achievement. Accounting students assume that the auditor's career can provide many opportunities to develop, recognition of achievement, respect for special skills, and easy to move up to motivate them to choose careers as auditors. The results of this study are in line with the results of Rahayu, Sudaryono, \& Setiawan (2003) regarding the factors that influence the career choice of accounting students. Among the factors studied, one of them is professional recognition, where professional recognition has a positive and significant effect in choosing the accounting student auditor's career.

Humans are born as social beings so that whatever their careers are, they will certainly socialize with their environment. The results of this study are in line with the results of research Senjari (2016) which concluded that social value variables did not have a significant effect on auditor career choice because consideration of high social values would reduce auditor career choices. 
At the beginning of pioneering the auditor's career, there may be many complaints due to complicated work, many challenges, and often overtime. The results of this study are in line with the Yendrawati (2007). Accounting students who choose a career as an auditor assume that everything that will happen in the auditor's work environment when he works later is a sacrifice that must be faced and for the accounting student the award or satisfaction he will get later is greater than the sacrifice he faces.

Significant results are because most accounting students assume that the auditor's career is guaranteed security and is much needed in various fields. Especially in the current era, many new companies were founded. Certainly, to produce good financial reporting, an auditor is needed. The results of this study are in line with Astuti (2014) research, labor market considerations are factors that influence students to choose auditor careers. Likewise, with the research of Yanti \& Ratnawati (2014) labor market consideration factors are things that are considered in choosing auditor career.

Personality includes a person is an attitude towards a job as well as whether the career requires high responsibility and discipline or not. Auditors need an independent attitude that is not easily influenced and impartial to anyone. However, this is not only needed in the auditor's career, but all good careers must also need good personalities. The insignificant results were caused by some students arguing that personality did not have a significant effect on the auditor's career. Rahayu, Sudaryono, \& Setiawan (2003) state that personality is one of the potential determinants of individual behavior when dealing with certain situations/conditions especially in choosing a career.

The phenomenon that happening now is someone wants to undergo a career to get a financial award/salary. The existence of high income/salary can be fulfilled daily needs. Accounting students assume that the auditor's career can guarantee a person's financial needs. This is in line with Yanti \& Ratnawati (2014) research which states that financial factors partially predominantly influence career choice of accounting student auditors.

\section{RESEARCH CONCLUSION AND LIMITATION}

\subsection{Conclusion}

The results of the study showed that financial appreciation, professional recognition, and market considerations have a positive and significant effect while professional training, work environment and personality have a positive and not significant effect on auditor career selection and social value variables that have a negative and insignificant effect on career choice as an auditor. Financial award is a dominant variable in the career choice of students as auditors.

\subsection{Limitation}

This study has limitations; it does not examine other factors that influence the choice of career as an auditor and only investigates within the scope of private universities. Further study should increase the scope of study by taking samples of accounting students from other public and private universities, also develop the study by examining other factors that influence career choice as auditors who were not examined in this study.

\section{REFERENCES}

Arens, A. A., Elder, R. J., \& Beasley, M. S. (2002). Auditing \& Jasa Assurance. Edisi Kelimabelas. Jakarta: Penerbit Erlangga. 
Astuti, A. (2014). Faktor-Faktor yang Mempengaruhi Mahasiswa Akuntansi dalam Memilih Karir sebagai Akuntan Publik pada Mahasiswa Akuntansi Universitas Kristen Satya Wacana Salatiga. Doctoral Dissertation. Salatiga: FEB-UKSW.

Boyce, C., Czajkowski, M., \& Hanley, N. (2018). Personality and economic choices. Journal of Environmental Economics and https://doi.org/10.1016/j.jeem.2018.12.004.

Crowley, C. B. (2017). Professional development as product implementation training. Teaching and Teacher Education, 67, 477-486. https://doi.org/10.1016/j.tate.2017.07.015.

List, J. A., Livingston, J. A., \& Neckermann, S. (2018). Do financial incentives crowd out intrinsic motivation to perform on standardized tests?. Economics of Education Review, 66, 125-136. https://doi.org/10.1016/j.econedurev.2018.08.002.

Lehmann, H., \& Pignatti, N. (2018). Informal employment relationships and the labor market: Is there segmentation in Ukraine?. Journal of Comparative Economics, 46(3), 838-857. Retrieved from https://doi.org/10.1016/j.jce.2018.07.011.

Merdekawati, D. P., \& Sulistyawati, A. I. (2012). Faktor-faktor yang mempengaruhi pemilihan karir akuntan publik dan non akuntan publik. Jurnal Ilmu Ekonomi ASET, 13(1). http://jurnal.widyamanggala.ac.id/index.php/asetwm/article/view/20.

Putra, S. E., \& Silfi, A. (2016). Faktor-Faktor Yang Mempengaruhi Minat Pemilihan Karir Mahasiswa Akuntansi Sebagai Auditor Pemerintah (Studi Empiris Mahasiswa Jurusan Akuntansi Ugm, Ui, Unri, Unand, Uin Suska Dan Uir). Jurnal Online Mahasiswa (JOM) Bidang Ilmu Ekonomi, 4(1), 353-365.

Rahayu, Sri, Sudaryono, E. A., \& Setiawan, D. (2003). Persepsi Mahasiswa Akuntansi Mengenai Faktor-Faktor Yang Mempengaruhi Pemilihan Karir. Simposium Nasional Akuntansi VI. Surabaya.

Ramdani, M. R., \& Kamidin, M. (2018). IMPLEMENTASI SAK-ETAP PADA UMKM WARKOP DI KOTA MAKASSAR. Jurnal RAK (Riset Akuntansi Keuangan), 3(2), 109-117. DOI: 10.31002/rak.v3i2.1069.

Sari, M. (2014). Faktor-Faktor Yang Mempengaruhi Pemilihan Karir Menjadi Akuntan Publik Oleh Mahasiswa Departemen Akuntansi Fakultas Ekonomi UMSU Medan. JRAB: Jurnal Riset Akuntansi \& Bisnis, 13(2). https://doi.org/10.30596/jrab.v13i2.148.

Senjari, R., Hasan, A., \& Sofyan, A. (2016). Pengaruh Motivasi, Lingkungan Kerja Dan Nilai Sosial Terhadap Minat Mahasiswa Akuntansi Dalam Memilih Karir Sebagai Akuntan Publik. Jurnal Online Mahasiswa (JOM) Bidang Ilmu Ekonomi, 3(1), 133-147. Retrieved from https://jom.unri.ac.id/index.php/JOMFEKON/article/view/10276.

Setyawardani, L. (2018) . Persepsi mahasiswa senior dan junior terhadap profesi akuntan. EKUITAS: Jurnal Ekonomi dan Keuangan, 13(1), 84-103. DOI: http://dx.doi.org/10.24034/j25485024.y2009.v13.i1.211.

Sulistyawati, A. I., Ernawati, N., \& Sylviana, N. (2013). Persepsi Mahasiswa Akuntansi Mengenai Faktor-Faktor Yang Mempengaruhi Pemilihan Karir. Jurnal Dinamika Akuntansi, 5(2). DOI: https://doi.org/10.15294/jda.v5i2.2990. 
Suyono, N. A. (2014). Analisis Faktor-Faktor yang Mempengaruhi Pemilihan Karir Sebagai Akuntan Publik (Studi Empiris pada Mahasiswa Akuntansi Unsiq). Jurnal Penelitian dan $\begin{array}{llll}\text { Pengabdian Kepada } \quad \text { Masyarakat } & \text { 69-83. }\end{array}$ https://doi.org/10.32699/ppkm.v1i2.235.

Tumiwa, A., Tewal, B., \& Palandeng, I. D. (2017). PENGARUH TEKNOLOGI INFORMASI, LINGKUNGAN KERJA DAN KOMPETENSI TERHADAP PRODUKTIVITAS KARYAWAN (STUDY PADA KANTOR PUSAT BANK SULUTGO). Jurnal EMBA: Jurnal Riset Ekonomi, Manajemen, Bisnis dan Akuntansi, 5(3). Retrieved from https://ejournal.unsrat.ac.id/index.php/emba/article/view/18194/18339.

Yanti, N., \& Ratnawati, V. (2014). Analisis Faktor-Faktor yang Mempengaruhi Mahasiswa Akuntansi dalam Pemilihan Karir Menjadi Akuntan Publik (Studi empiris pada Perguruan Tinggi Negeri dan Swasta di Pekanbaru). Jurnal Online Mahasiswa (JOM) Bidang Ilmu Ekonomi, 1(2), 1-15.

Yendrawati, R. (2007). Persepsi mahasiswa dan mahasiswi akuntansi mengenai faktor-faktor yang mempengaruhi pemilihan karir sebagai akuntan. Jurnal Fenomena, 5(2), 1-11.

*) Muhammad Reza Ramdani, Department of Accounting, University of Muslim Indonesia, Makasar, Indonesia (Email : reza.ramdani@umi.ac.id)

**) Andi Muara Arumbarkah, Department of Accounting, University of Muslim, Makasar, Indonesia (Email : muaraarumbarkah@umi.ac.id)

***) Ismi Ayu Lestari, BTFD Public Accountant, Makasar, Indonesia (Email : Ismiayulestari22@gmail.com) 